\title{
Butyramide-utilizing Mutants of Pseudomonas aeruginosa 8602 which Produce an Amidase with Altered Substrate Specificity
}

\author{
By JANE E. BROWN, P. R. BROWN AND PATRICIA H. CLARKE \\ Department of Biochemistry, University College London, \\ London W.C. I. \\ (Accepted for publication 21 April 1969)
}

\section{SUMMARY}

Mutants of Pseudomonas aeruginosa 8602 were isolated which, unlike the wild type, were able to grow with butyramide as a carbon source. Six mutants derived from the constitutive strain $\mathrm{C} 11$ were shown to produce an enzyme (B amidase) with altered electrophoretic mobility and altered substrate specificity. The apparent $K_{m}$ for butyramide of the B amidase was about a tenth of that of the A amidase and the $V_{\max }$ was about ten-fold greater. A further mutation produced mutants able to grow on valeramide.

\section{INTRODUCTION}

Pseudomonas aeruginosa 8602 grows in a minimal medium containing either acetamide or propionamide as a carbon + nitrogen source, and both these amides induce the synthesis of an aliphatic amidase (acylamide amidohydrolase EC 3.4.14). This organism is unable to utilize butyramide for growth and Kelly \& Clarke (1962) found that acetamide-grown bacteria (and extracts prepared from them) had very little amidase activity with butyramide as a substrate and that butyramide did not induce amidase synthesis in a succinate + minimal salt medium. The magno-constitutive mutant C 11 (Brammar, Clarke \& Skinner, 1967) is also unable to grow on butyramide and produces an enzyme which is indistinguishable from the wild-type amidase. We have now obtained mutants of strain $\mathrm{C} 11$ which grow on agar plates and in liquid medium with butyramide as the carbon source. The amidase produced by one of these butyramide-utilizing mutants has been purified and compared with that produced by strain $\mathrm{C} 11$.

\section{METHODS}

Organisms. The parent strain was Pseudomonas aeruginosa 8602 . Strain $\mathrm{C} 11$ was a spontaneous mutant, constitutive for amidase (Brammar et al. 1967) and was used to isolate the butyramide-utilizing mutants designated B I to B 6 (see later for genetic descriptions).

Media. The minimal salt medium described by Brammar \& Clarke (1964) was used for all growth experiments; solid media contained $\mathrm{I} \cdot 2 \%(\mathrm{w} / \mathrm{v})$ Oxoid No. 3 agar. Lactate and pyruvate media were prepared by adding sterile solutions of the sodium or potassium salts aseptically to autoclaved minimal salt medium. Butyramide plates contained $0.1 \%(\mathrm{w} / \mathrm{v})$ and valeramide plates $0.2 \%(\mathrm{w} / \mathrm{v})$ of the specific amide, and were prepared by adding sterile solutions of the amides to minimal agar. Other media were prepared as described by Brammar et al. (1967). 
Mutagen treatment. Bacteria were grown overnight with shaking at $37^{\circ}$ in $5 \mathrm{ml}$. of nutrient broth. The bacteria were centrifuged down, resuspended in $4 \mathrm{ml}$. citrate buffer (0.I M; pH 6.0), I ml. aqueous solution of $N$-methyl- $N^{\prime}$-nitro- $N$-nitrosoguanidine ( $\mathrm{Img}$. $/ \mathrm{ml}$.) was added and the suspension allowed to stand for $40 \mathrm{~min}$. at room temperature. The bacterial suspension was centrifuged again, the deposit suspended in $5 \mathrm{ml}$. dilution buffer and $0.2 \mathrm{ml}$. of this spread on each of several butyramide or valeramide plates.

Transduction. Phage lysate preparation and transduction procedure were as described by Brammar et al. (1967).

Growth of bacteria for enzyme studies. Organisms for enzyme experiments were grown at $37^{\circ}$ in conical flasks of capacity 5 to 10 times the volume of medium and were shaken. For enzyme preparations the bacteria were grown in 51 . conical flasks containing I 1 . of $0.5 \%(\mathrm{w} / \mathrm{v})$ pyruvate or lactate medium.

Preparation of cell-free extracts. Bacteria grown overnight in $200 \mathrm{ml}$. of I \% (w/v) pyruvate medium were centrifuged down and then suspended in $2 \mathrm{ml}$. of ice-cold tris

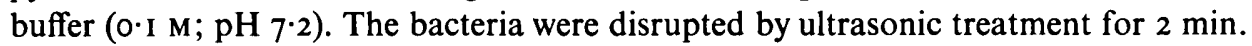
at $0^{\circ}$ by using an MSE $25 \mathrm{~W}$ ultrasonic oscillator. Debris was removed by centrifugation at $25,000 \mathrm{~g}$ for $20 \mathrm{~min}$. at $4^{\circ}$. The supernatant fluids were stored at $-30^{\circ}$. Large scale preparations of extracts for enzyme purification were made by re-suspending bacteria (equiv. $65 \mathrm{mg}$. dry wt/ml.) in ice-cold tris buffer and disrupting in a RibiSorvall fractionator at a pressure of 15,000 to 20,000 p.s.i. $\left(\mathrm{lbs} / \mathrm{inch}^{2}\right)$; the needle valve was cooled throughout the operation by a stream of nitrogen at $0^{\circ}$.

Enzyme purification. The mixture obtained after cell disruption was treated with streptomycin sulphate (I g. $/ 6 \mathrm{~g}$. protein), homogenized and centrifuged at I I,000 $\mathrm{g}$ for $30 \mathrm{~min}$. at $4^{\circ}$ to remove cell debris and precipitated nucleic acid; $250 \mathrm{ml}$. portions of the supernatant fluid were heated rapidly to $60^{\circ}$, maintained at that temperature for $8 \mathrm{~min}$. and then cooled rapidly to $0^{\circ}$. The heat-treated solutions were bulked and centrifuged at I I,000 $\mathrm{g}$ for $20 \mathrm{~min}$. at $4^{\circ}$. Fractionation of the supernatant fluid was done by ammonium sulphate precipitation; precipitates were collected by centrifugation (I I,000 $\mathrm{g}$ for $20 \mathrm{~min}$.) after 50, 55, 65 and $75 \%$ saturation with ammonium sulphate. At each stage the solutions were allowed to stand at $0^{\circ}$ for $30 \mathrm{~min}$. before centrifuging. The $\mathrm{P}_{65}$ fraction (55 to $65 \%$ saturation with ammonium sulphate) contained the bulk of the amidase activity and was dissolved in tris $(0 \cdot 1 \mathrm{M} ; \mathrm{pH} 7 \cdot 2)$ buffer containing $0 \cdot 15 \mathrm{M}-\mathrm{KCl}$, dialysed against two changes of the same buffer and centrifuged at $15,000 \mathrm{~g}$ to remove any precipitate. The dialysis and subsequent operations were done at room temperature. The protein solution was loaded on to a column of DEAE-Sephadex previously equilibrated with the same buffer; the column was washed for $2 \mathrm{hr}$ with this buffer before a linear concentration gradient from $0.15 \mathrm{M}$ to $0.35 \mathrm{M}-\mathrm{KCl}$ in a total volume of 21 . tris buffer was applied to the column. Fractions containing the major $280 \mathrm{~m} \mu$-absorbing peak were assayed for amidase and samples from each fraction examined by disc electrophoresis in polyacrylamide gels (Davis, 1964). Fractions shown to be homogeneous for the amidase enzyme by this method were bulked. A small portion of this material was retained for enzyme work and stored at $-30^{\circ}$; the bulk was dialysed against $0 \cdot \mathrm{I} \mathrm{M}-\mathrm{KCl}$ and precipitated by exhaustive dialysis against deionized water. The precipitate was extracted with ethanol + ether and stored at $4^{\circ}$ for use in structural studies.

Enzyme assays. Enzyme activity was routinely measured by the transferase assay 
described by Brammar \& Clarke (1964). Final concentrations of amides in the substrate mixture were acetamide $0.1 \mathrm{M}$, propionamide $0.125 \mathrm{M}$, butyramide and isobutyramide $0.15 \mathrm{M}$. Hydrolase activity was measured by estimating the ammonia produced in the reaction by the Conway microdiffusion method (Kelly \& Clarke, 1962). This method could not be used with valeramide, since in the presence of saturated $\mathrm{K}_{2} \mathrm{CO}_{3}$ valeramide formed a film on the surface of the reaction mixture which prevented ammonia diffusion. With valeramide as a substrate in the hydrolase reaction the ammonia was measured by its reaction with ninhydrin. Samples (0.I $\mathrm{ml}$.) were removed from the incubation mixture (bacterial suspension; $0 . \mathrm{I} \mathbf{M}, \mathrm{pH} 7 \cdot 2$ tris buffer; $0.2 \mathrm{M}$-valeramide) and added to I ml. $0.2 \mathrm{M}$-citrate buffer ( $\mathrm{pH} 5^{\circ}$ ), I ml. ninhydrin reagent added, the mixture heated at $100^{\circ}$ for $15 \mathrm{~min}$. and after the addition of $5 \mathrm{ml} .50 \%(\mathrm{v} / \mathrm{v})$ ethanol in water the extinction was measured at $570 \mathrm{~m} \mu$ with a Unicam SP 600 spectrophotometer. The ninhydrin reagent (modification suggested by P. D. Laverack) was freshly prepared I hr before use by adding $0.1 \mathrm{ml}$. KCN solution (0.I M-KCN diluted I/I5) dropwise to Io ml. 2-methoxyethanol followed by $2 \mathrm{ml} .3 \%$ $(\mathrm{w} / \mathrm{v})$ ninhydrin in 2-methoxyethanol. Ester hydrolase and transferase activities were measured by the methods described by McFarlane, Brammar \& Clarke (1965).

Enzyme units. One unit of transferase activity is defined as the amount of enzyme catalysing the formation of $\mathrm{I} \mu$ mole acylhydroxamate/min. under the standard assay conditions. One unit of hydrolase activity is defined as the amount of enzyme catalyzing the formation of I $\mu$ mole ammonia/min. under the standard assay conditions.

Estimation of protein. The method of Lowry, Rosebrough, Farr \& Randall (I95I) was used for protein estimation, with bovine plasma albumin as a standard.

Buffers. Tris buffer, $0.1 \mathrm{M}, \mathrm{pH} 7 \cdot 2$, was used to prepare bacterial suspensions and for enzyme assays; $0.00 \mathrm{I}$ M-EDTA and $0.025 \%$ (v/v) mercaptoethanol were added for assays with purified enzyme preparations and at all stages of amidase purification. Barbitone + acetate buffer, $\mathrm{pH} 8.6$, ionic strength $I 0.05$, +0.0I $\mathrm{M}-\mathrm{NaN}_{3}$ was used for immunodiffusion tests.

Reagents. Tris (2-amino-2-hydroxymethylpropane-I:3 diol) was obtained as 'Trizma base' from the Sigma Chemical Co. Acetamide obtained from Hopkins \& Williams Ltd. was recrystallized twice from ethanol before use. Propionamide and butyramide were obtained from British Drug Houses Ltd. and were recrystallized twice from ethanol. Isobutyramide was prepared from isobutyryl chloride and ammonia and was recrystallized from ethyl acetate. Hydroxylamine hydrochloride from Koch-Light Ltd. was recrystallized twice from ethanol + water $(3+\mathrm{I}, \mathrm{v} / \mathrm{v})$. $N$-methyl- $N^{\prime}$-nitro- $N$-nitrosoguanidine was obtained from the Aldrich Chemical Co. Inc. Hydrolysed starch was obtained from Connaught Medical Research Laboratories. Esters were obtained from British Drug Houses Ltd. and were used without further purification. Complete Freund's Adjuvant was obtained from Difco Laboratories Inc. Deionized water was used to prepare all solutions involved in the enzyme purification.

Starch gel electrophoresis. Starch gel electrophoresis was done as described by Gammack, Huehns, Shooter \& Gerald (1960) with the discontinuous tris + citrate + borate buffer system at $\mathrm{pH} 8 \cdot 5$. Gels were sliced and one slice was stained for protein with a saturated solution of naphthalene black in methanol + water + acetic acid $(5+5+$ I by vol., for $5 \mathrm{~min}$.). The background stain was washed out with the same solvent. Gel slices were stained for amide hydrolase activity by overlaying with a filter paper soaked with a solution of the appropriate amide, incubating for $15 \mathrm{~min}$. at $37^{\circ}$ 
and replacing the filter paper by one soaked in Nessler's reagent. Yellow bands on the filter paper indicated the position of the amidase protein. Amide transferase activity was detected by incubating a gel slice overlaid with a filter paper soaked in the mixed substrate solution for $15 \mathrm{~min}$. at $37^{\circ}$, and replacing the filter paper by one soaked in the ferric chloride reagent; the position of the amidase was shown by the formation of a brown band on the surface of the gel.

Immunodiffusion. Rabbit antiserum against the purified c 11 enzyme was prepared by giving rabbits two intramuscular injections, spaced by an interval of 4 weeks, of $0.75 \mathrm{ml}$. of an emulsion of equal volumes of a solution of purified enzyme $(8 \mathrm{mg} . / \mathrm{ml}$. in tris buffer) and Freund's complete adjuvant. An intravenous booster dose of $0.5 \mathrm{ml}$. of enzyme solution was given after a further 2 weeks. The rabbits were bled a week later; blood was allowed to clot at $4^{\circ}$, centrifuged and the serum obtained was stored at $-30^{\circ}$. The serum was not further purified and was used either undiluted or diluted $1 / 2$ with normal saline in immunodiffusion tests. Immunodiffusion was done in agar gels $(2 \mathrm{ml}$. $1 \%(\mathrm{w} / \mathrm{v})$, Difco agar Noble in barbitone + acetate buffer on microscope slides, $2.5 \times 7.5 \mathrm{~cm}$.). Wells were cut with a No. 2 cork borer; $10 \mu \mathrm{l}$. samples were placed in the outer wells and Io $\mu$ l. antiserum in the centre well. Precipitin lines were developed in a moist environment at room temperature, or in the case of the extracts of $\mathrm{V}$ mutants at $4^{\circ}$, and were photographed after $20 \mathrm{hr}$.

\section{RESULTS}

\section{Isolation of butyramide-utilizing mutants}

Pseudomonas aeruginosa strain $\mathrm{C} 11$ is a spontaneous constitutive mutant which was isolated on succinate + formamide (SF) plates (Brammar et al. 1967). Formamide can be hydrolysed by induced bacteria at about one-sixth the rate for acetamide but formamide has almost no amidase-inducing activity for the wild-type strain. Constitutive mutants have therefore a selective advantage over the wild type in their ability to use formamide for growth. $P$. aeruginosa cannot metabolize $\mathrm{C}_{1}$ compounds so that formamide provides only the nitrogen source and succinate is added as carbon source. It was argued that a single mutation in the amidase structural gene of strain $\mathrm{C} 11$, which produces a very high amidase activity in the absence of inducer, might produce a new mutant which would be able to grow on butyramide. After mutagenic treatment, about $10^{7}$ bacteria were plated on butyramide agar and after 2 to 3 days colonies appeared. A few of the larger ones were picked off and re-isolated from butyramide agar. The mutants chosen for further study were designated B I to B 6 . The growth characteristics of the mutants and the parent strains are given in Table I. Brammar et al. (1967) showed that for a series of regulator mutants, all of which produced wildtype enzyme, the character for constitutivity was co-transduced with the amidasepositive character and concluded that an amidase regulator gene was closely linked to the amidase structural gene. In previous investigations the amidase mutants have been named so as to indicate their phenotypic behaviour but we now propose to introduce the genetic descriptions $a m i R$ for the amidase regulator gene and $a m i E$ for the amidase structural gene. This follows the recommendations of Demerec, Adelberg, Clark \& Hartman (1966).

We have previously isolated a number of amidase-negative mutants (Skinner \& Clarke, I968) and these have now been assigned the genetic descriptions amiEI to 
amiE 10. The genetic description of the regulator gene mutants, including both constitutive and formamide-inducible mutants (Brammar et al. 1967), becomes amiRI to $a m i R 30$. It is particularly convenient for the other investigations we are doing to retain a very simplified nomenclature indicating the phenotype, and for general descriptive purposes we are continuing to use our previous nomenclature, e.g. C 11 indicates a constitutive strain isolated on succinate + formamide agar, producing wild-type enzyme and with a mutation $(a m i R 11)$ in the amidase regulator gene. The butyramide mutants described in the present paper were isolated from strain $\mathrm{C} 11$ and shown to produce altered enzymes. Mutant B 6 is therefore a constitutive mutant which produces a mutant enzyme protein and has the genetic description amiR 11amiE I6 (Table I).

Table I. Growth characteristics of Pseudomonas aeruginosa 8602 wild type and mutants

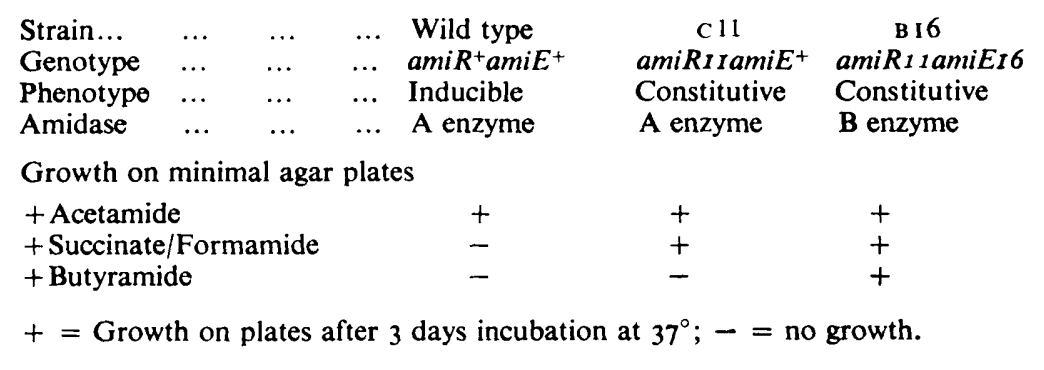

\section{Amidase activities of intact bacteria}

Kelly \& Clarke ( I 962) showed that for the wild-type Pseudomonas aeruginosa 8602 strain, although acetamide was the most potent of the substrate inducers, the amide most rapidly hydrolysed was propionamide. The enzyme is also able to transfer the acyl moiety of the amides to hydroxylamine to form hydroxamates. It was found that for this reaction the rate of hydroxamate formation from acetamide was greater than that from propionamide. During growth the physiological role of the enzyme is amide hydrolysis so that it is reasonable to expect a difference in the rates of hydrolysis of butyramide as between mutants able to grow on butyramide and the parent strain $\mathrm{C} 11$ which is unable to do so.

Figure I compares the rates of hydrolysis of formamide, acetamide, propionamide, lactamide, isobutyramide and butyramide by washed suspensions of strain $\mathrm{C} 11$ and its mutant $\mathbf{B} 6$. The hydrolysis rates for the various amides are expressed in relation to an arbitrary value of 100 for acetamide hydrolysis. The specific acetamide hydrolase activities of these two strains grown under the same conditions did not differ markedly, although it appeared that the cultures of the B mutants were usually slightly less active than those of strain $\mathrm{C} 11$. It can be seen that the relative rate of butyramide hydrolysis by mutant $\mathrm{B} 6$ was about 15 times that of $\mathrm{C} 11$ and that $\mathrm{B} 6$ also had a higher relative rate for the hydrolysis of propionamide, lactamide and isobutyramide. The substrate profiles for hydrolase activity for mutants B I and B 2 did not differ significantly from that obtained for $\mathbf{B} 6$.

Figure 2 compares the relative transferase activities of strains $\mathrm{C} 11$ and $\mathrm{B} I$ and shows that $\mathrm{B} I$ was much more active than $\mathrm{C} 11$ with the longer chain amides as substrates. 
Only trace activity $(<\mathrm{I} \%$ ) was detected with butyramide and isobutyramide as transferase substrates for strain $\mathrm{C} 11$, but the relative transferase activities of mutant $\mathrm{B} I$ with these two substrates were 12 and $3 \%$, respectively, of the rates with acetamide. The relative rate of propionyl transfer by $\mathrm{B}$ I was twice that of $\mathrm{C} 11$. The substrate profiles for transferase activity of the other five mutants (в2 to в6) were, as for the hydrolase activities, not significantly different from that shown for mutant B I.

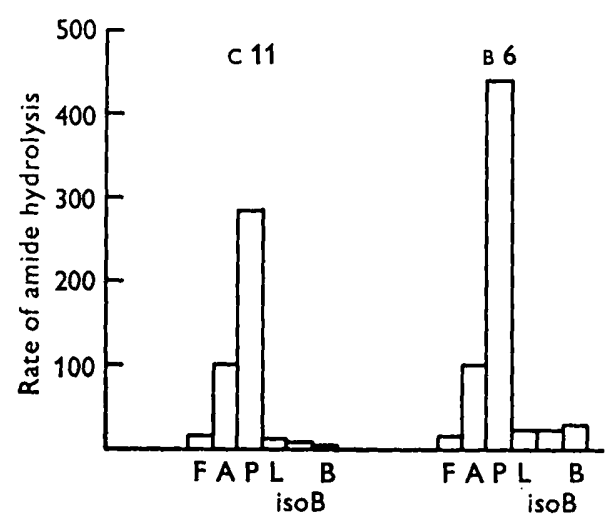

Fig. I

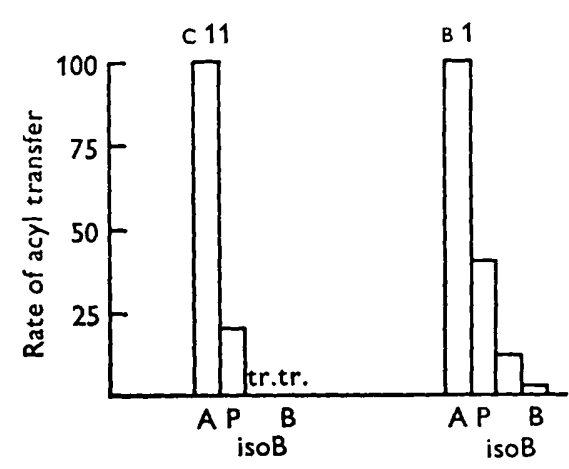

Fig. 2

Fig. 1. Relative hydrolase activities of washed suspensions of Pseudomonas aeruginosa 8602 strain C11, and strain B 6. F, formamide; A, acetamide; P, propionamide; L, lactamide; isoB, isobutyramide; $B$, butyramide.

Fig. 2. Relative acyl transferase activities of washed suspensions of Pseudomonas aeruginosa 8602 strain C 11, and strain B I. A, acetamide; P, propionamide; isoB, isobutyramide; B, butyramide; tr, trace.

The increased amidase activities of the B mutants on the higher molecular-weight amides might have been due to differences in amide permeability. Brammar, McFarlane \& Clarke (I966) showed that the wild type possesses a constitutive permease which enables it to concentrate both acetamide and $\mathrm{N}$-acetylacetamide from the medium. Although the permeability of the bacteria for butyramide and the other amides has not been tested directly it seems unlikely that the difference in amidase activities between strain $\mathrm{C} 11$ and the $\mathrm{B}$ mutants could be accounted for in terms of permeability. Pseudomonas aeruginosa 8602 and its mutants appear to be freely permeable to amides (perhaps via a single permease) and the relative acyl transferase activities of $\mathrm{C} 11$ and the B mutants were found to be the same with cell extracts as with whole bacteria.

\section{Amidase activity of bacterial extracts}

Magno-constitutive mutants grown in pyruvate or lactate media, in which there is little catabolite repression, produced large amounts of amidase constituting $5 \%$ or more of the total bacterial protein. When cell-free extracts were subjected to starch-gel electrophoresis, the amidase was observed as a major protein band. One of the slices of the gel was stained with naphthalene black for protein and other slices were stained for acetamide hydrolase and transferase activities. The amidase band in extracts of strain B 6 moved more slowly than that of strain C11. In mixtures of extracts from the two strains the two separate amidase bands could be identified. The amidase band 
from extracts of $\mathrm{B} 6$ and the slower moving band in the mixtures gave strong butyramide hydrolase and transferase reactions. Slight butyramide hydrolase activity was shown with $\mathrm{C} 11$ extracts when the gels were very heavily loaded and this was always associated with the acetamide hydrolase and transferase activities. These observations suggested that the differences between strain $\mathbf{B} 6$ and strain $\mathrm{C} 11$ were due to the production of an amidase with altered substrate activity. The electrophoretic mobilities of the amidases in cell extracts of all the B mutants were identical.

\section{Comparison of $C 11$ and $B 6$ amidases}

From the preceding observations it was concluded that mutant $\mathrm{B} 6$ was able to grow on butyramide because it produced an altered enzyme (B enzyme) as a result of a mutation in the gene which determines the structure of the wild-type amidase (A enzyme). This relationship was confirmed by genetic studies. In transduction tests, with B mutants as donors and amidase-negative mutants as recipients, amidasepositive transductants were found at a frequency comparable with that obtained in crosses between the wild type and amidase-negative mutants. Approximately $90 \%$ of the amidase-positive transductants in the crosses with the B mutants were shown by replication tests to be also butyramide-positive and constitutive. This association of constitutivity with the amide-positive character was similar to that found previously in crosses between constitutive amidase-positive mutants and inducible amidase-negative mutants (Brammar et al. 1967).

\section{Table 2. Purification and recovery of $A$ amidase from Pseudomonas aeruginosa strain C11}

Amidase A from strain $\mathrm{C} 11$ grown in 1001 . minimal salt medium containing $1 \%(\mathrm{w} / \mathrm{v})$ sodium lactate was purified 19 -fold. Amidase activity was determined as acetamide transferase. $\left(\mathrm{NH}_{4}\right)_{2} \mathrm{SO}_{4}$ fractions were resuspended in the minimal volume of tris buffer and dialysed before assay. Fraction $\mathbf{P}_{65}$ was loaded on a DEAE-Sephadex column.

\begin{tabular}{|c|c|c|c|}
\hline & $\begin{array}{l}\text { Volume } \\
\text { (ml.) }\end{array}$ & $\begin{array}{c}\text { Total enzyme } \\
\text { units } \times 10^{-4}\end{array}$ & $\begin{array}{l}\text { Total protein } \\
\text { (g.) }\end{array}$ \\
\hline Bacterial suspension & 1100 & 730 & c. 80 \\
\hline $\begin{array}{l}\text { Cell-oxtract after strepto- } \\
\text { mycin and heat treatment } \\
\left(\mathrm{NH}_{4}\right)_{2} \mathrm{SO}_{4} \text { fractions }\end{array}$ & 1120 & 650 & $13 \cdot 2$ \\
\hline $\begin{array}{l}P_{50}(0-50 \% \text { sat. }) \\
P_{55}(50-55 \% \text { sat. })\end{array}$ & - & $\begin{array}{l}5 \cdot 4 \\
2 \cdot 8\end{array}$ & $\begin{array}{l}4 \cdot 35 \\
0 \cdot 068\end{array}$ \\
\hline$P_{65}(55-65 \%$ sat.) & 一 & 540 & $3 \cdot 6$ \\
\hline $\mathbf{P}_{75}(65-75 \%$ sat.) & 一 & 65 & $4 \cdot 85$ \\
\hline $\begin{array}{l}\text { * Tube } 50 \text { from DEAE- } \\
\text { Sephadex column }\end{array}$ & $3 \cdot 7$ & $8 \cdot 8$ & 0.051 \\
\hline
\end{tabular}

- Specific activity of amidase in Tube $50=1700 ;+$, total enzyme recovered from tubes around amidase peak $2 \times 10^{8}$ units $\equiv 30 \%$ of amidase in cell-extract.

Table 2 shows the recovery of amidase activity at various stages of a typical purification procedure of a preparation from strain $\mathrm{C} 11$. The final step involved chromatography on DEAE-Sephadex; the elution profile for the $\mathrm{C}_{11}$ enzyme is shown in Fig. 3. The purification was monitored by disc electrophoresis on acrylamide gels. There was no significant difference in the behaviour of the A and B enzymes at any stage in purification. The ratio of acetamide to butyramide transferase activities of the $B$ 
enzyme remained constant throughout purification with a ratio of I I I with whole bacteria, 10.5:I with cell extracts and I0: I with the pure enzyme preparation.

Immunodiffusion experiments showed that there was complete cross-reaction between cell extracts, or purified amidase preparations, of strains $\mathrm{C} 11$ and B 6 with antiserum prepared against the purified enzyme from strain C11. Complete crossreaction was also found in the reciprocal experiment with antiserum prepared against the purified amidase from strain $\mathbf{B} 6$.

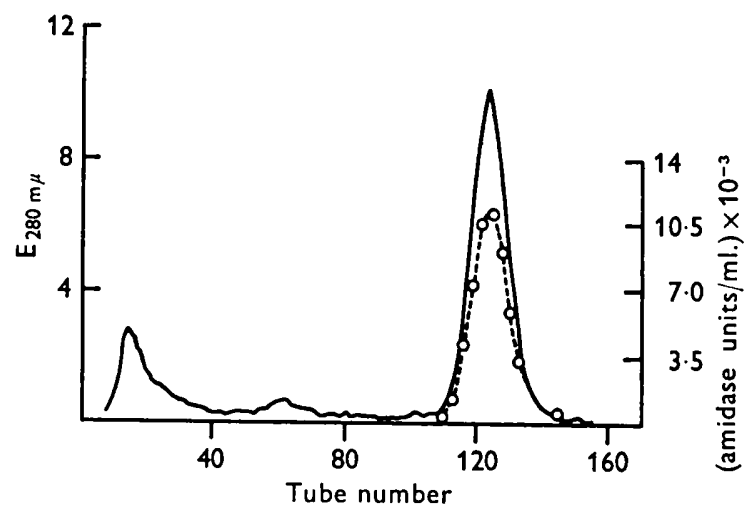

Fig. 3. Chromatography of amidase A from Pseudomonas aeruginosa 8602 strain $\mathrm{C} 11$ on DEAE-Sephadex. Elution of amidase by gradient of $\mathrm{KCl}$ in tris buffer (see Methods); column loaded with $\left(\mathrm{NH}_{4}\right)_{2} \mathrm{SO}_{4}$ fraction $\mathbf{P}_{65}$. Amidase assayed by acetamide transferase reaction. - - O -.- O--., amidase $\mu$ mole acethydroxamate $/ \mathrm{min} . / \mathrm{ml}$; — (extinction $280 \mathrm{~m} \mu$ ). $6.3 \mathrm{ml}$. fractions were collected.

Both A and B amidases were very stable in crude bacterial extracts; these could be stored at $-30^{\circ}$ for several months without loss of activity. The purified preparations, even in the presence of protective agents such as mercaptoethanol and EDTA, slowly lost activity on prolonged storage. It was difficult to obtain very accurate values for the specific activity of the pure enzyme since some activity was always lost during the preparation of the very dilute solutions necessary for enzyme assays. The highest values for the A enzyme gave a specific activity for acetamide transferase of about I $800 \mu$ mole acethydroxamate $/ \mathrm{mg}$. protein $/ \mathrm{min}$. The highest value obtained for the $B$ enzyme suggested that its acetamide transferase activity was about $80 \%$ of that of the A enzyme. The results with whole bacteria had suggested that the specific acetamide hydrolase and transferase activities/mg. dry wt bacteria of cultures of the B mutants were slightly lower than those of strain $\mathrm{C} 11$ grown in the same medium. Fig. 4 compares the hydrolase activities of purified preparations of A and B amidases on acetamide and butyramide. The rate of hydrolysis of butyramide by the A enzyme was only a small fraction (about $2 \%$ ) of the rate of hydrolysis of acetamide, while the rate of hydrolysis of butyramide by the B enzyme was about $30 \%$ of the rate of acetamide hydrolysis. The specific butyramide hydrolase activity of the B enzyme was therefore about 10 times that of the A enzyme.

When determinations were made of the apparent Michaelis constants of the A and $B$ amidases in the transferase reaction for acetamide, propionamide and butyramide, by using the Lineweaver-Burk method, it was evident that at very high butyramide concentrations the A enzyme had low but significant activity on butyramide (Fig. 5). 
In all our subsequent estimations the concentration of butyramide in the substrate mixture for both hydrolase and transferase assays was increased to $0.5 \mathrm{M}$. Kelly \& Kornberg (1964) had previously used $0.2 \mathrm{M}$-butyramide to assay purified amidase from the wild-type strain and at this concentration had not been able to detect any butyramide hydrolase or transferase activity.

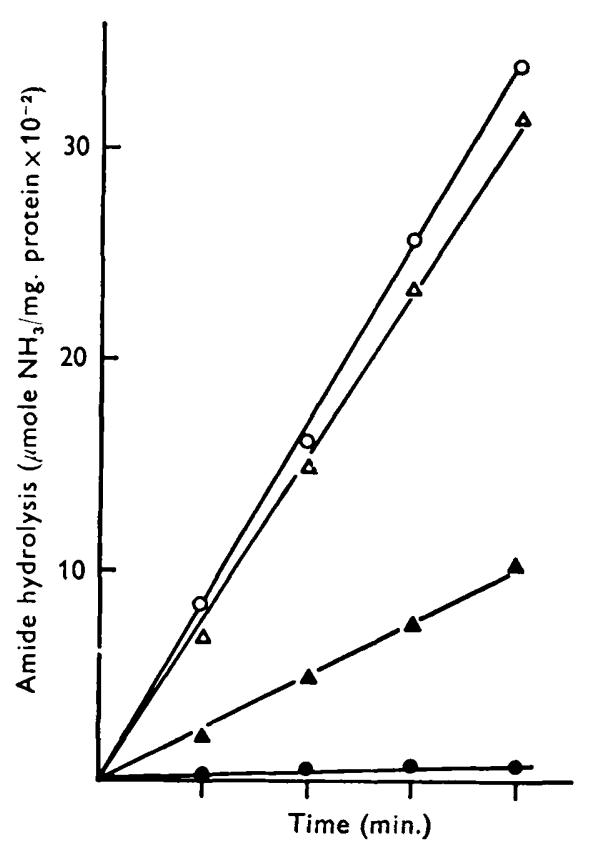

Fig. 4

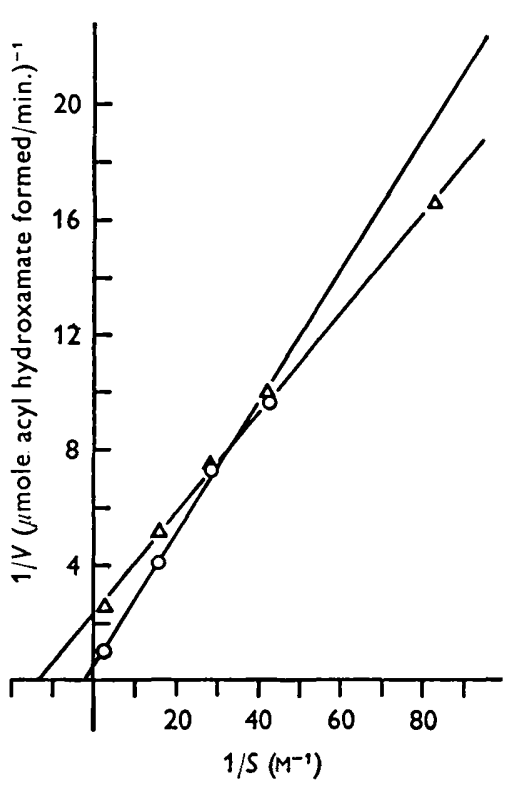

Fig. 5

Fig. 4. Amide hydrolysis by A and B amidases. Enzyme activity measured by the Conway microdiffusion method. Amide concentration $0.2 \mathrm{M}$. A amidase on acetamide, $\mathrm{O} \ldots \mathrm{O}$; on butyramide,.$--\mathbf{B}$ amidase on acetamide, $\triangle \cdots \triangle$; on butyramide, $\Delta-\cdots \mathbf{\Delta}$.

Fig. 5. Lineweaver-Burk plot for determination of $K_{m}$ for butyramide in the transforase reaction of $\mathbf{A}$ and $\mathbf{B}$ amidases. $\bigcirc--\mathrm{O}, \mathbf{A}$ amidase; $\triangle \cdots \triangle, \mathbf{B}$ amidase.

Table 3. Comparison of $A$ and $B$ amidases: apparent Michaelis constants

$\begin{array}{lcc} & \begin{array}{c}\text { A amidase. } \\ \text { *Apparent } K_{m} \text { mM }\end{array} & \begin{array}{c}\text { B amidase. } \\ \text { *Apparent } K_{m} \text { mM }\end{array} \\ \text { Acetamide } & 19 & 15 \\ \text { Propionamide } & 55 & 9 \cdot 5 \\ \text { Butyramide } & 500 & 73.5\end{array}$

* Determined for the transferase reaction in the presence of excess hydroxylamine.

Figure 5 shows that there was about a ten-fold difference in the apparent $K_{m}$ for butyramide of the A and B enzymes. The theoretical $V_{\max }$ values obtained from the same plot also showed about a Io-fold difference. The $V_{\max }$ of the A amidase for butyramide was $19.5 \mu$ mole hydroxamate $/ \mathrm{mg}$. protein $/ \mathrm{min}$. and the $V_{\max }$ for the B amidase for butyramide was $190 \mu$ mole hydroxamate $/ \mathrm{mg}$. protein $/ \mathrm{min}$. The apparent $K_{m}$ of the B enzyme for propionamide was also less than that of the A enzyme 
but there did not seem to be any significant difference in the $K_{m}$ values of the two amidases for acetamide (Table 3).

\section{Esterase activity of $A$ and $B$ amidases}

McFarlane et al. (1965) showed that the wild-type amidase also had limited activity as an esterase. The rate of both hydrolase and transferase activity of the purified enzyme with ethyl acetate as substrate was about I \% of that with acetamide in the same reactions. The esterase activity of the $\mathrm{B}$ enzyme was comparable to that of the $\mathrm{A}$ enzyme but ethyl propionate, isopropyl acetate and butyl acetate were more rapidly attacked (Table 4). These esters are all only very slightly soluble in water and all determinations were made with saturated aqueous solutions. This is probably well below substrate saturating concentration of the enzyme since McFarlane et al. (1965) found that the apparent $K_{m}$ for ethyl acetate, the most water-soluble of the esters used, was $660 \mathrm{~mm}$. However, it is clear that the differences in substrate specificity of the $\mathbf{A}$ and $\mathbf{B}$ amidases also extends to the ester substrates.

Table 4. Ester transferase activity

\begin{tabular}{lccc} 
Methyl acetate & \multicolumn{2}{c}{ A amidase } & B amidase. \\
Ethyl acetate & 70 & 72 & ND \\
Transferase
\end{tabular}

The esterase activity is expressed relative to that for ethyl acetate arbitrarily assigned a value of 100 . ND $=$ Not determined.

Table 5. Valeramide-utilizing mutants

\begin{tabular}{|c|c|c|c|c|c|c|}
\hline \multirow[b]{2}{*}{ Mutant } & \multicolumn{3}{|c|}{${ }^{*}$ Growth on amides } & \multicolumn{3}{|c|}{$\begin{array}{c}\text { †Amide hydrolysis ( } \mu \text { mole } \\
\mathrm{NH}_{3} / \mathrm{mg} \text {. bact./min.) }\end{array}$} \\
\hline & Acet. & But. & Val. & Acet. & But. & Val. \\
\hline VI & + & +++ & ++ & 0.49 & $2 \cdot 7$ & 0.44 \\
\hline $\mathbf{v} 2$ & - & +++ & ++ & ND & ND & ND \\
\hline v3 & $+t+$ & +++ & ++ & $3 \cdot 0$ & $6 \cdot 5$ & 0.61 \\
\hline$v_{4}$ & $++t$ & +++ & ++ & $3 \cdot I$ & $8 \cdot 1$ & 0.56 \\
\hline$v 5$ & tr & $+t+$ & ++ & 0.85 & $3 \cdot 1$ & 0.64 \\
\hline v6 & ++ & +++ & ++ & 3.7 & $9 \cdot 3$ & 0.78 \\
\hline v7 & + & +++ & ++ & 0.68 & $3 \cdot I$ & 0.7 \\
\hline v8 & $+t+$ & +++ & ++ & $3 \cdot 4$ & $8 \cdot I$ & 0.62 \\
\hline v9 & + & + & ++ & 0.8 & 0.98 & 0.48 \\
\hline VIO & + & + & ++ & 0.55 & 0.57 & 0.38 \\
\hline v 11 & + & + & ++ & 0.83 & 0.56 & 0.42 \\
\hline B 6 & $+t+$ & $++t$ & - & $9 \cdot 4$ & $3 \cdot 3$ & 0 \\
\hline C 11 & $+t+$ & - & - & 15.5 & 0.3 & 0 \\
\hline
\end{tabular}

* Growth was tested on minimal agar plates containing $0.5 \%(w / v)$ acetamide, $0.1 \%$ (w/v) butyramide acid or $0.2 \%(w / v)$ valeramide and recorded after 3 days at $37^{\circ} .+++,++,+$, tr. = relative growth. $-=$ no visible growth; + Amide hydrolysis was measured by the ninhydrin method. ND = Not determined. 


\section{Valeramide-utilizing mutants}

One of the butyramide-utilizing mutants, B 6, was used to isolate a further series of mutants able to grow on valeramide. These formed a heterogenous group and a few of them have lost the ability to grow on acetamide agar. Table 5 compares the hydrolase activity of whole bacteria of the $\mathrm{v}$ series of mutants with acetamide, butyramide or valeramide as substrates. For all these mutants the specific acetamide hydrolase activity was less than that of cultures of strains conditions. Several of the $v$ mutants had much higher specific butyramide-hydrolase activities than strain B 6 and washed suspensions of all the $v$ strains were able to hydrolyse valeramide at a significant rate.

The amidase proteins of all the $v$ mutants appeared to be much less stable than the $A$ and $B$ amidases since the enzyme activity was rapidly lost when the bacteria were disrupted. The extracts were examined by immunodiffusion against the antiserum to the $\mathrm{A}$ and $\mathrm{B}$ amidases and for all those tested the cross-reaction obtained was only partial. The double mutation in the amidase structural gene of the $v$ mutants appears to have produced alterations in the enzyme protein which affect the antigenic specificity as well as the substrate specificity.

\section{DISCUSSION}

The double mutation which has changed the wild-type Pseudomonas aeruginosa 8602 into mutant $\mathbf{B} 6$ has increased its range of growth substrates. It may be considered as a positive evolutionary step for this organism in that it can now grow on a substrate which the wild type cannot use. The procedure of starting from a constitutive mutant seemed logical since butyramide appeared to have no inducing activity for the wildtype strain (Kelly \& Clarke, 1962). However, this procedure was less straightforward than it at first appeared. Butyramide, like cyanoacetamide, represses the induction of amidase by $\mathrm{N}$-acetylacetamide in the wild-type strain and it also represses to a considerable extent the synthesis of amidase by the constitutive strain $\mathrm{C} 11$ (Brown, 1969). The mutation which produced strain $\mathrm{B} 6$ from $\mathrm{C} 11$ affected the properties of the enzyme, but not its regulation, and the rate of amidase synthesis by strain $\mathrm{B} 6$ appears to be repressed by butyramide to about the same extent as the synthesis by C 11 . Mutant B 6 is therefore able to grow in butyramide medium because the B amidase has a higher activity than the wild-type $\mathrm{A}$ amidase for butyramide as substrate. On the other hand, we have isolated other mutants which grow on butyramide but produce wild-type A amidase. These are constitutive mutants which have also become relatively insensitive to butyramide repression. In butyramide medium they synthesize large amounts of A amidase and, although the specific activity towards butyramide is much lower than that of the B amidase, the total amount of enzyme produced by the culture is sufficient to allow growth to occur (Brown, 1969).

Wu, Lin \& Tanaka ( 1968 ) have also isolated mutants able to grow on a carbon source not utilized by a wild-type strain. Klebsiella (Aerobacter) aerogenes grows in a minimal medium with the ribitol as carbon source, but is not able to grow on xylitol. Ribitol induces the synthesis of ribitol dehydrogenase and this enzyme has some activity with xylitol as a substrate, but xylitol does not induce its synthesis. Wu et al. (I968) obtained a series of mutants of $K$. aerogenes which were able to grow on xylitol and the first mutant $\mathrm{X} I$ was found to be constitutive for ribitol dehydrogenase. From 
this mutant they isolated a faster-growing mutant $\mathrm{X} 2$ which produced an altered enzyme with a higher affinity for xylitol as a substrate. The apparent $K_{m}$ for xylitol of the ribitol dehydrogenase from mutant X2 was $120 \mathrm{~mm}$ as compared with $290 \mathrm{~mm}$ for mutant XI; the corresponding values for ribitol were $25 \mathrm{~mm}$ and $31 \mathrm{~mm}$. They obtained a further mutant $\mathrm{x}_{3}$ which was constitutive for a permease system which accepts xylitol but normally transports D-arabitol. Since even the altered ribitol dehydrogenase had a very low affinity for xylitol as a substrate, the active concentration of xylitol by a permease gave this mutant a growth advantage over both $\mathrm{X} I$ and $\times 2$. Adaptation to growth on a novel substrate in this case involved structural and regulator genes for ribitol dehydrogenase and an unrelated permease.

Kelly \& Clarke (1962) examined the substrate range of the wild-type amidase Pseudomonas aeruginosa: it was limited by the size of the amide side chain. The relative rates of hydrolysis of the aliphatic amides were formamide $\ll$ acetamide $<$ propionamide. The substituted amides glycollamide and acrylamide were hydrolysed at rates intermediate between acetamide and propionamide. We have now shown that butyramide, isobutyramide and lactamide are all hydrolysed at low rates. The Pseudomonas aeruginosa в 6 mutation results in an enzyme which is able to hydrolyse these latter amides at higher specific rates; this suggests that the substrate binding site of the B enzyme more readily accepts them as substrates. The additional mutations, which allow growth on valeramide, shifted the substrate range even further in favour of amides with larger side chains and in a few cases the specific rate of acetamide hydrolysis had dropped to such an extent that the mutant was unable to grow on acetamide. Extensive physicochemical comparisons have been made between the $\mathrm{A}$ and $\mathrm{B}$ amidases but no significant differences have yet been detected in overall composition or in the peptide fragments obtained after trypsin hydrolysis or cleavage with cyanogen bromide, in spite of the very clear cut difference in the electrophoretic mobilities of the two enzymes (P. R. Brown, unpublished). The A and B amidases may differ in a single amino acid located at or near the substrate-binding site of the enzyme. However, the alteration might be at another position in the polypeptide chain, producing an alteration in the conformation of the enzyme protein which allowed it to accept butyramide more readily. It would have been interesting to have compared the A and B amidase with the enzymes produced by the $\mathrm{V}$ mutants since the latter would be expected to have at least two amino acid alterations. The finding that only partial cross-reaction occurred between extracts of the $\mathrm{v}$ mutants and antiserum to the $\mathrm{A}$ amidase indicated that there were structural differences between the enzyme proteins. Unfortunately the instability of the $\mathrm{V}$ amidases in the cell-free state made it impossible to purify the active enzyme proteins.

Pollock (1965) compared two penicillinases from different strains of Bacillus licheniformis and found that there were slight differences in the electrophoretic mobilities, and considerable differences in the enzyme constants. The maximum specific activities of the two enzymes differed by a factor of 6 and the substrate affinities differed also by a factor of 6 but in the opposite direction. This meant that $V_{\max } / K_{m}$ for the two enzymes was almost identical and Pollock (I965) suggested that this represented the physiological efficiency of the enzyme in that at low substrate concentrations which might be encountered in a natural habitat the two enzymes would hydrolyse penicillin at about the same rate. Our A and B amidases have approximately Io-fold differences in respect to both $V_{\max }$ and $K_{m}$ with butyramide in the transferase 
reaction. The rate of butyramide hydrolysis by the $\mathrm{A}$ enzyme was so low that it was technically difficult to determine these parameters for butyramide in the hydrolase reaction. If ratios of the $K_{m}$ and $V_{\max }$ values for butyramide hydrolase activities of the $\mathrm{A}$ and $\mathrm{B}$ amidases are comparable with those for the butyramide transferase activities, then the physiological efficiencies of the $A$ and $B$ amidases with respect to growth on butyramide may differ by a factor of about 100 .

In our system the mutation-producing strain $\mathbf{B} 6$ seems to have resulted in a very marked difference in substrate specificity without significant loss of activity towards its former substrates. We have usually taken acetamide transferase activity as the norm in comparing the activities of mutant enzymes, since this has the highest specific rate of all the reactions known to be catalysed by the wild-type enzyme: amide and ester hydrolysis; acyl transfer, from amides, acids and esters. However, the physiological role of the enzyme during growth on amides depends on the rate of amide hydrolysis and propionamide was found to be hydrolysed more rapidly by suspensions of the B mutants than by the strain producing wild-type enzyme. The $K_{m}$ for propionamide in the transferase reaction of the B enzyme was less than that of the A enzyme and if we can extrapolate this to the hydrolase reaction, then with propionamide hydrolysis as the norm the B mutant amidase could be said to have a higher physiological efficiency than the wild-type enzyme, together with an alteration in specificity range in favour of higher chain length amides.

\section{REFERENCES}

Brammar, W. J. \& Clarke, P. H. (1964). Induction and repression of Pseudomonas aeruginosa amidase. J. gen. Microbiol. 37, 307.

Brammar, W. J., Clarke, P. H. \& Skinner, A. J. (1967). Biochemical and genetic studies with regulator mutants of the Pseudomonas aeruginosa 8602 amidase system. J. gen. Microbiol. 47, 87.

Brammar, W. J., McFarlane, N. D. \& Clarke, P. H. (I966). The uptake of aliphatic amides by Pseudomonas aeruginosa. J. gen. Microbiol. 44, 303.

Brown, J. E. (1969). Regulator and structural gene mutants of Pseudomonas aeruginosa amidase. Ph.D. Thesis, University of London.

Davis, B. J. (1964). Disc eloctrophoresis-II. Method and application to human serum proteins. Ann. N.Y. Acad. Sci. 121, 404.

Demerec, M., Adelberg, E. A., Clark, A. J. \& Hartman, P. E. (1966). A proposal for a uniform nomenclature in bacterial genetics. Genetics, Princeton 54, 6I.

Gammack, D. B., Huehns, E. R., Shooter, E. H. \& Gerald, P. (1960). Identification of the abnormal polypeptide chain of haemoglobin $\mathrm{G}_{1 \mathrm{~b}}$.J. molec. Biol. 2, 372.

Kelly, M. \& Clarke, P. H. (1962). An inducible amidase produced by a strain of Pseudomonas aeruginosa. J. gen. Microbiol. 27, 305.

Kelly, M. \& Kornberg, H. L. (1964). Purification and properties of acyltransferases from Pseudomonas aeruginosa. Biochem. J. 93, 557.

Lowry, O. H., Rosebrough, N. J., Farr, A. L. \& Randall, R. J. (1951). Protein measurement with the Folin phenol reagent. J. biol. Chem. 193, 265.

McFarlane, N. D., Brammar, W. J. \& Clarke, P. H. (1965). Esterase activity of Pseudomonas aeruginosa amidase. Biochem. J. 95, $24 \mathrm{C}$.

Pollock, M. R. (I965). Purification and properties of penicillinases from two strains of Bacillus licheniformis: A chemical, physiochemical and physiological comparison. Biochem. J. 94, 666.

Skinner, A. J. \& Clarke, P. H. (1968). Acetate and acetamide mutants of Pseudomonas aeruginosa 8602. J. gen. Microbiol. 50, 183.

Wu, T. T., Lin, E. C. C. \& TANAKA, S. (1968). Mutants of Aerobacter aerogenes capable of utilizing xylitol as a novel carbon source. J. Bact. 86,447 . 